Available online at

http://jifnp.tp.ugm.ac.id
INDONESIAN FOOD AND NUTRTIION PROCRESS

Indonesian Food and Nutrition Progress, 2014, Vol. 13, Issue 1

\title{
Isolation and Characterization of The Functional Properties of The Major Protein Fraction from Nyamplung (Calophyllum inophyllum)
}

\author{
Muhammad Prima Putra and Pudji Hastuti ${ }^{*}$ \\ Graduate Programme of Estate Crop Product Technology, Faculty of Agricultural Technology, \\ Universitas Gadjah Mada, Jl. Flora 1, Bulaksumur, Yogyakarta 55281, Indonesia \\ ${ }^{*}$ Corresponding author. Tel.: +62274549650; Fax.: +62274549650. E-mail: hastutipudji@yahoo.com \\ Received 26 May 2014; Accepted 15 August 2014; Published Online 10 September 2014
}

\begin{abstract}
Defatted nyamplung (Calophyllum inophyllum) seeds as by-products of oil extraction is a rich source of protein. In order to evaluate its potential as value-added of nyamplung seeds, nyamplung proteins were isolated by solubilization-precipitation method at $\mathrm{pH} 3$ and 5 . The obtaining protein isolates were characterized with respect to their functional properties, including water binding capacity, oil binding capacity, foaming capacity, foaming stability, emulsifying activity, emulsifying stability, gelation capacity, and amino acid composition. The results show that nyamplung protein could be considered as high protein quality because essential amino acids leucine (4.39\%), proline $(4.22 \%)$, valine (3.34 \%), aspartic acid (3.23 \%) and lysine (3.34 \%) were found to be the major amino acids. Polar amino acids were higher than non-polar amino acid (1.7 times). With the consequence in higher ratio of water binding capacity to oil binding capacity ( 2.7 times) and high value of hydrophile-lypophile balance. In general, the isolated protein from precipitation at $\mathrm{pH} 3$ (IP3) was found to have better functional properties than that being precipitated at $\mathrm{pH}$ (IP5), and showed excellent in water binding, emulsifying, gelation and foaming properties. In conclusion, IP3 can be utilized as high quality proteins and emulsifier in oil in water emulsion system.
\end{abstract}

Keywords: nyamplung (Calophyllum inophyllum), protein isolates, functional properties, water binding capacity, emulsifier

\section{Introduction}

Recently, nyamplung (Calophyllum inophyllum) is an oil seed, gains a big attention as a source of bio-fuel (Sudradjat, 2009; Venkanna and Reddy, 2009; Asralian, 2009). The oil content of nyamplung is 61-75\% db (Crane et al., 2005; Bustomi et al., 2008; Asralian, 2009). In Indonesia, nyamplung can be found almost in all islands cover 480,000 ha with an annual production over 500,000 tons per year (Bustomi et al., 2008; Sudradjat, 2009). It grows in areas with annual rainfall ranging from about 1000 to $5000 \mathrm{~mm}$.

The cakes from oil extraction, as a byproduct, still have high concentration of protein (30\%, unpublished data). It is very potential source for protein isolate, animal feed, fertilizer and chemical-based materials. Many studies on the characteristics and functional properties of proteins have been reported from various oilseeds, such as crambe seed (Massoura et al., 1998), soybean and lupin seed (Rodriguez-Ambris et al., 2005), sesame seed (Gandhi and Srivastava, 2007), rapeseeds (Yoshie-Stark et al., 2008), bayberry kernel (Cheng et al., 2009), sunflower seeds (Pickardt et al., 2009), and sweet lupin seed (Jayasena et al., 2010). However, the characteristics and functional properties of nyamplung protein isolate have not been explored yet. The process of isolation and fractionation of proteins might affect the functional properties of the proteins. In order to explore its potential as protein resources for industrial applications, a study was done to isolate the protein by solubilization of protein at $\mathrm{pH} 10$ and further precipitation at $\mathrm{pH} 3$ (IP3) or $\mathrm{pH} 5$ (IP5). Protein isolates were evaluated with respect to the 
chemical compositions and its functional properties including, water- and oil-binding capacity, foaming capacity, foaming stability, emulsifying capacity, emulsifying stability and gelation capacity.

\section{Materials and Methods Materials}

Nyamplung seed and palm oil were provided from local suppliers in Yogyakarta, Indonesia. $\mathrm{NaOH}, \mathrm{HCl}$, methanol, triethylamine, sodium acetate, TRIZMA, and 2-mercaptoethanol were purchased from Merck KGaA (Darmstadt, Germany). Acetonitrile was purchased from Sigma-Aldrich Ltd (St. Louis, MO, USA).

\section{Preparation of Sample}

The seeds were shelled and the kernels were separated and crushed. The oil was extracted by hydraulic press, followed by solvent extraction using hexane. The defatted material was air-dried at ambient temperature and crushed again followed by sieving ( 80 mesh). The defatted flour was stored in a refrigerator at $7^{\circ} \mathrm{C}$ prior to analysis.

\section{Isolation of Protein}

Defatted nyamplung flour was dispersed in distilled water $(1: 20, \mathrm{w} / \mathrm{v})$. The $\mathrm{pH}$ was adjusted to 11.0 using $1 \mathrm{~N} \mathrm{NaOH}$ at $30^{\circ} \mathrm{C}$. After 2 $\mathrm{h}$, it was centrifuged at $4000 \mathrm{~g}$ for $30 \mathrm{~min}$. The supernatant was decanted. The residue was extracted again to obtain high yield of proteins. The supernatants were combined and separated into 2 parts. The proteins were precipitated by adjusting $\mathrm{pH}$ to 3.0 (IP3) and 5.0 (IP5), respectively. The precipitated proteins were recovered by centrifugation at $4000 \mathrm{~g}$ for $30 \mathrm{~min}$. Protein curd was washed twice with distilled water and freezedried.

\section{Composition Analysis}

Concentration of water, ash, fat and crude protein were determined according to the method of standard Association of Official Analytical Chemists (AOAC, 1990).

\section{Water and Oil Binding Capacity}

Water and oil binding capacity were determined as described by Manak et al., (1980). One $\mathrm{g}$ of protein isolate was added into $10 \mathrm{~mL}$ of distilled water and palm oil in a weighted centrifuge tube for determination of binding capacity of water and oil, respectively. The mixture was homogenized for $30 \mathrm{~s}$ every $5 \mathrm{~min}$ using a Vortex stirrer. After $30 \mathrm{~min}$, the tubes were centrifuged at $4000 \mathrm{rpm}$ for $20 \mathrm{~min}$. The free water or palm oil was decanted. The amount of bound water or oil was measured by weighing. The binding capacity of water or oil was expressed as the amount of water or oil retained per $100 \mathrm{~g}$ of proteins.

\section{Foaming Capacity and Foam Stability}

The foaming capacity (FC) and foam stability (FS) of the protein isolates were determined as described by Sathe et al., (1982). For FC determination, protein solution was prepared by adding protein isolate into distilled water $(1 \% \mathrm{w} / \mathrm{v})$. The $\mathrm{pH}$ was adjusted to 7 by $1 \mathrm{~N}$ $\mathrm{NaOH}$. It was further homogenized using Nissei AM 10 homogenizer at $10,000 \mathrm{rpm}$ for $5 \mathrm{~min}$. The foam volume was determined. FC values were calculated using Eq. (1):

$$
F C=\frac{\text { foam volume }(\mathrm{ml})}{\text { total volume of suspension }(\mathrm{ml})} \times 100
$$

On the other hand, FS was evaluated over a period of $2 \mathrm{~h}$ and determined base on the remained foam volume at $15,30,60,90$ and 120 min. It was calculated using Eq. (2):

$$
F S=\frac{\text { foam volume }(\mathrm{ml}) \text { at time } t}{\text { initial foam volume }(\mathrm{ml})} \times 100
$$

\section{Emulsifying Activity and Emulsion Stability}

Emulsifying capacity (EA) and emulsion stability (ES) were determined as described by Naczk et al., (1985) with slightly modification. Protein isolate was added into distilled water (1\% $\mathrm{w} / \mathrm{v}$ ). The $\mathrm{pH}$ was adjusted to 7 by $1 \mathrm{~N} \mathrm{NaOH}$. The solution was homogenized at 10,000 rpm using Nissei AM 10 homogenizer. Five $\mathrm{mL}$ of palm oil was added gradually to the solution with continuous stirring. Another $5 \mathrm{~mL}$ of oil was added. Volume of the emulsion layers was determined. EA was calculated using Eq. (3):

$$
E A=\frac{\text { volume of emulsion layer }(\mathrm{ml})}{\text { total volume of suspension }(\mathrm{ml})} \times 100
$$


The ES was determined by heating the emulsion, as prepare before, for $15 \mathrm{~min}$ at $85^{\circ} \mathrm{C}$, followed by cooling and centrifugation at 3,000 $\mathrm{g}$ for $5 \mathrm{~min}$. The emulsion stability was expressed as the percentage of remained emulsifying activity after heating at $\mathrm{pH} 7$.

\section{Least Gelation Concentration}

The least gelation concentration (LGC) was determined according to the method of Sathe et al., (1982). Test tube containing of 2, 4, 6, 8, 10, $12,14,16,18$, and $20 \%(\mathrm{w} / \mathrm{v})$ protein isolate in distilled water $(5 \mathrm{~mL})$ were heated for $1 \mathrm{~h}$ in the boiling water followed by cooling in ice. Temperature was maintained at $4{ }^{\circ} \mathrm{C}$ for $2 \mathrm{~h}$. LGC was defined as the minimum protein concentration, in which the formed gel did not flow when the test tube was inverted.

\section{Amino Acid Analyses}

Protein isolate $(250 \mathrm{mg})$ was hydrolyzed using $5 \mathrm{ml} 6 \mathrm{~N} \mathrm{HCl}$ at $110{ }^{\circ} \mathrm{C}$ for $24 \mathrm{~h}$ and further derivatized with solution containing of methanol, $\mathrm{Na}$-acetate and triethylamine for $20 \mathrm{~min}$ at $25{ }^{\circ} \mathrm{C}$. The hydrolyzed protein was then analyzed by HPLC at ambient temperature using PICO TAG 3.9 x $150 \mathrm{~nm}$ column using a gradient system with 1 M sodium acetate $\mathrm{pH} 6.0$ and $60 \%$ acetonitrile. Detector was set at $254 \mathrm{~nm}$. Chart speed and run time were $2 \mathrm{~cm} / \mathrm{min}$ and 32 min., respectively. Amino acid composition was expressed as $\mathrm{g}$ of amino acid per $100 \mathrm{~g}$ of protein.

\section{Colour Evaluation}

Colour of protein isolate was determined using a Minolta Chroma Meter CR-300 (Minolta Camera Co., Osaka, Japan). Measured values were expressed as L; a; $b$ colour units, where $\mathrm{L}=$ lightness, $+\mathrm{a}=$ redness, $-\mathrm{a}=$ greenness, $+\mathrm{b}=$ yellowness, $-b=$ blueness.

\section{Results and Discussion Isolation of Protein}

The compositions of nyamplung seed and defatted flour are shown in Table 1. De-oil process of nyamplung seeds caused an increase in all concentrations of flour components due to a decrease in cake oil concentration. Protein and carbohydrate concentrations increased 3.9 and 2.8 times, respectively. $\mathrm{nHigh}$ protein concentration of flour $(30.4 \%)$ is suggested that the defatted flour was very potential as protein resource for food and non-food application. It was comparable with the defatted Lesquerella fendleri flour (31.8\%) (Hojilla-Evangelista and Evangelista, 2009). However, it was slightly lower compared with the defatted of jatropha flour, bayberry flour, rapeseed flour, Lupinus compestris and soybean flour, in which the values were $56.4 \%$, $60.5 \%, 48.2 \%, 55.3 \%$ and $52.4 \%$, respectively (Rodriguez-Ambris et al., 2005; Makkar et al., 1997; Cheng et al., 2009; Yoshie-Stark et al., 2008).

Isolation of protein using solubilizationprecipitation technique resulted in protein recovery of $54.88 \pm 7.37 \%$ and $44.27 \pm 5.27 \%$ for IP3 and IP5, respectively. Protein concentration of protein isolates were $91.25 \pm 0.04 \%$ and $87.42 \pm$ $1.15 \%$ for IP3 and IP5, respectively. Low recovery of protein might be due to their retention in the residue and the forming of protein complex with other molecules such as lipid and carbohydrate. The protein yield was comparable with the result of beach pea protein isolate (59.4-67\%) (Chavan et al., 2001), but it was 2 times higher than cotton seed protein isolate (Tsaliki et al., 2003).

Table 1. Composition of nyamplung seed and defatted flour

\begin{tabular}{lcc}
\hline & Seed & Defatted flour \\
\hline Moisture (\%) & $6.37 \pm 1.02$ & $20.97 \pm 3.87^{*}$ \\
Ash (\% db) & $1.86 \pm 0.05$ & $4.91 \pm 0.67$ \\
Protein (\% db) & $7.67 \pm 0.96$ & $30.43 \pm 3.83$ \\
Lipid (\% db) & $69.39 \pm 6.90$ & $0.89 \pm 0.14$ \\
Carbohydrate $(\% \mathrm{db})$ & $14.69 \pm 6.83$ & $41.78 \pm 4.81$ \\
\hline
\end{tabular}

*Moisture content including solvent.

\section{Amino Acid Composition}

Amino acid composition is one of the factors that affect the functional properties of protein. The results demonstrated that protein isolates from nyamplung were rich in lysine, leucine, proline, aspartic acid and glutamic acid but they limited in tryptophan, methionine and cysteine (Table 2). Since IP3 and IP5 had most of the essential amino acids, they could be considered as a high quality protein.

Polar amino acids are the primary site of protein-water interaction, and non-polar amino acids affect protein-lipid interaction by hydrophobic interaction. IP3 had polar amino acids such as glycine, proline, tyrosine, threonine, lysine, arginine, histidine, aspartic acid and glutamic acid. There were not significantly different on the total polar amino acids in IP3 (23.2\%) and in IP5 (22.7\%). Total non-polar amino 
acids in IP3 (13.28\%) were also not significant difference comparing with IP5 (13.42\%). However, it was suggested that amino acid compositions affected the capacity of water binding, oil binding, gelation, emulsion and foaming due to their interaction and conformational formation as shown on Table 3.

Table 2. Amino acid composition of nyamplung protein isolates

\begin{tabular}{lcc}
\hline Amino acid & $\begin{array}{c}\text { IP3 } \\
\text { (g/100g) }\end{array}$ & $\begin{array}{c}\text { IP5 } \\
(\mathrm{g} / 100 \mathrm{~g})\end{array}$ \\
\hline Glycine & 0.67 & 0.65 \\
Alanine & 1.16 & 1.17 \\
Valine & 3.34 & 2.98 \\
Isoleucine & 1.34 & 1.42 \\
Leucine & 4.39 & 4.68 \\
Prolin & 4.22 & 4.29 \\
Phenylalanine & 1.18 & 1.21 \\
Tyrosine & 1.88 & 1.89 \\
Serine & 1.83 & 2.22 \\
Threonine & 1.47 & 1.32 \\
Methionine & 1.18 & 1.27 \\
Cystine & 0.69 & 0.68 \\
Aspartic acid & 3.23 & 3.10 \\
Glutamic acid & 6.28 & 5.98 \\
Histidine & 0.98 & 1.06 \\
Arginine & 1.12 & 1.08 \\
Lysine & 3.34 & 3.42 \\
\hline *IP3:Isoelectric point $\mathrm{pH} 3, \mathrm{IP} 5:$ Isoelectric $\mathrm{point} \mathrm{pH}$
\end{tabular}

*IP3:Isoelectric point pH 3, IP5: Isoelectric point pH5

\section{Functional Properties}

The functional properties of nyamplung protein isolate are shown in Table 3. IP3 had higher capacity of both water binding and foaming than IP5, but it did not have significantly difference in the capacity of oil binding, gelation and emulsifying.

\section{Water Binding Capacity}

The degree of water-protein interaction determines the water binding capacity of protein. Results showed that water binding capacity of IP3 was 1.7 times higher than IP5 (Table 3). It may be due to the difference in the average of protein charge at pH 7. IP3 had lower average pl (3) than IP5 (5). It may result in more negative charge at $\mathrm{pH} 7$ than IP5. Therefore, water-protein interaction was more effective in IP3.
Water binding capacity also depended on polar amino acids availability on the primary sites of protein for protein-water interactions (Zayas, 1997). However, the calculated amino acid polar side chain of IP3 (23.2\%) and IP5 (22.7\%) were not significantly different. The results suggested that protein conformation and the presents of protein complex with other molecules such as, carbohydrate, tannin and lipid may also have important role in water binding capacity. Water binding capacity of IP3 was comparable with Lupinus angustifolius seed protein isolate, bayberry protein isolate, cotton seed protein isolate, in which the values were $446.7 \%, 300 \%$ and 470\%, respectively (Lqari et al., 2002; Cheng et al., 2009; Tsaliki et al., 2003).

\section{Oil Binding Capacity}

Oil binding capacity is one of the important functional properties of food product. It has an important role in mouth feel and flavour retention. Oil binding capacity of IP3 and IP5 were not significantly different (Table 3 ). The results were consistent with the calculated non-polar amino acids, in which they were also not significantly different with non-polar amino acids. It indicated that oil binding capacity has a correlation with the lipophilic amino acid contents (Zayas, 1997).

Oil binding capacity of isolates was lower comparing with their water binding capacity is. This result was also consistent with a

high ratio of polar amino acids to non-polar amino acids of proteins (1.7 times). The oil binding capacities were comparable with the protein isolates of bayberry, Lupinus campestris, soy bean and Lupinus angustifolius, in which the values were $180 \%, 170 \%, 150 \%$, and $195 \%$, respectively (Cheng et al., 2009; Rodriguez-Ambriz et al., 2005; Lqari et al., 2002).

\section{Gelation Capacity}

Heating of protein solution at certain concentration will induce gel formation. LGC is defined as the lowest protein concentration at which gel remain in the inverted tube. It is used as an index of gelation capacity. The lower LGC means that the better of the gelating ability of the protein ingredient. Results showed that protein concentration of $8 \%$ was required to form a protein gel at pH 7.0. LGC was not significantly different with of IP3 and IP5 (Table 3). LGC of nyamplung protein isolates were lower comparing 
with Lupinus angustifolius protein isolate, chickpea protein isolate, indian chickpea and mucuna bean protein concentrates, in which the values were $10 \%, 14 \%, 14 \%$ and $12 \%$, respectively (Lqari et al., 2002; Zhang et al., 2007; Kaur and Singh, 2007; Adebowalea and Lawal, 2003). Thus results indicated that nyamplung protein isolates had a better gelating capacity than these other proteins and they may be used as gelating agent.

Table 3. Functional Properties of Nyamplung Protein Isolate

\begin{tabular}{lcc}
\hline Protein Properties & IP3 & IP5 \\
\hline Water binding & $431.03 \pm$ & $252.44 \pm$ \\
capacity $(\% \mathrm{w} / \mathrm{w})$ & 8.31 & 3.07 \\
Oil binding capacity & $155.92 \pm$ & $171.74 \pm$ \\
(\% w/w) & 12.44 & 13.88 \\
Gelation capacity $(\%$ & & \\
w/v) & 8 & 8 \\
Emulsifying capacity & $59.15 \pm$ & $56.23 \pm$ \\
(\% v/v) & 0.37 & 0.4 \\
Emulsifying stability & $55.07 \pm$ & $10.06 \pm$ \\
$(\%$ v/v) & 2.28 & 0.21 \\
Hydrophilic & & \\
Lypophilic Balance & $>16.7$ & $>16.7$ \\
Foaming capacity $(\%$ & $145.33 \pm$ & $49.83 \pm$ \\
v/v) & 1.15 & 0.76 \\
\hline
\end{tabular}

\section{Emulsifying Properties}

Nyamplung protein isolates contained both hydrophilic and hydrophobic amino acid fractions. Interaction of protein with both water and oil in a water-oil system has an important role in stabilization of emulsion. Table $\mathbf{3}$ showed that EA of IP3 was not significantly different with IP5. Both protein isolates had high HLB, indicated that they could stabilize oil in water emulsion system. The finding was consistent with high ratio of water to oil binding capacity of IP3 and IP5, namely 2.7 and 1.5 , respectively. EA was slightly higher comparing with Lequerella fendleri seed of $32.3 \%$ (Hojilla-Evangelista and Evangelista, 2009) and bayberry protein isolate of $48.7 \%$ (Cheng et al., 2009).

The values of ES were affected by various factors including $\mathrm{pH}$, droplet size, net charge, interfacial tension, viscosity, and protein conformation (Hung and Zayas, 1991). The results showed that ES of IP3 was 5.5 times higher than IP5. The finding was consistent with higher ratio of water to oil binding capacity of IP3 (2.7) than IP5 (1.5). Since IP5 had lower net charge due to higher pl of IP5 comparing with IP3, the results suggested that low ES of IP5 may be attributed to low net charge of protein. Thus, the high ES may be attributed to the dissociation of some proteins, and the forming of the resulting subunits had more hydrophobic groups which interacted more strongly with the lipid phase (Mahajan and Dua, 1995).

\section{Foaming Capacity and Stability}

The results show that FC of IP3 was 2.9 times higher than IP5 (Table 3). It may be due to higher net charge of IP3 at pH 7 than that of IP5 because of the deprotonated carboxyl groups of proteins at higher $\mathrm{pH}$ than that of their pl. High net charge will weakened the hydrophobic interactions, and it increases the flexibility of the protein. As a result, it allows the protein to diffuse more rapidly into the air-water interface to encapsulate air particles and then enhances the foam formation (Aluko and Yada, 1995). The finding was consistent with the fact that IP3 had high ratio of water to oil binding capacity. Comparing with an other reported data, FC of IP3 was comparable with the protein isolates of beach pea and Lupinus angustifolius, in which the values of FC were $128-143 \%$ and $116-119 \%$, respectively (Chavan et al., 2001; Lqari et al., 2002).

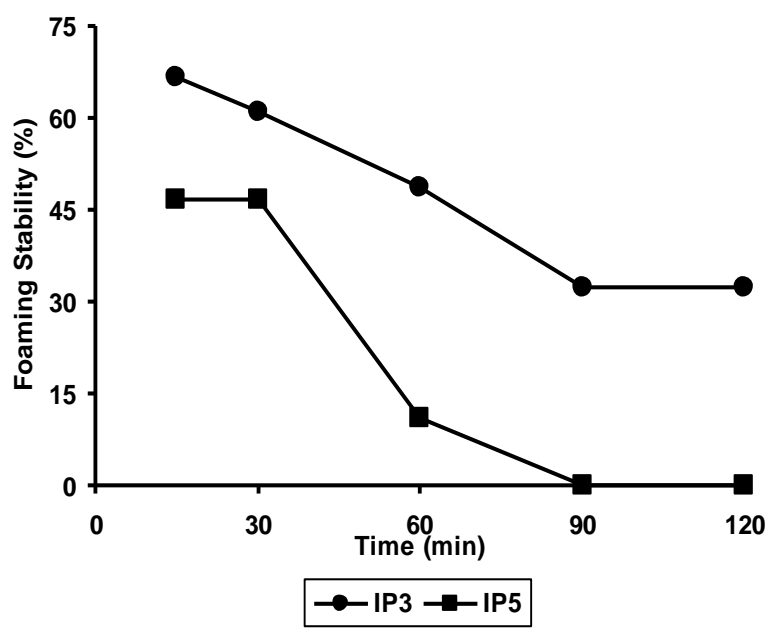

Fig. 1 Foaming stability of IP3 ( ) and IP5 ( $)$ disperse in distilled water as function of time at $\mathrm{pH} 7$

As shown in Fig. 1, FS of IP3 was found to be higher than IP5, and it remained $32.23 \%$ after $120 \mathrm{~min}$, but the foam of IP5 was completely lost after $60 \mathrm{~min}$. Better FS of IP3 may be due to the difference in the electrostatic repulsion. It is suggested that electrostatic repulsion increases with an increase in $\mathrm{pH}$ due to the deprotonated of carboxyl groups of proteins. As a result, the 
ability of protein to interact with water to encapsulate air particles becomes better. FS of nyamplung protein isolates was lower than the protein isolate of beach pea and Lupinus angustifolius, in which the foam still remained 90.1\% after $60 \mathrm{~min}$ and $94.8 \%$ after $120 \mathrm{~min}$, respectively (Chavan et al., 2001; Lqari et al., 2002).

\section{Colour of Protein Isolates}

The colour of protein isolates may limit the use of protein in foods. Colour determination of nyamplung proteins showed dark brown with the values of $L, a$ and $b$ as shown in Table 4 . The results indicated that the covalent binding between phenolic compounds and reactive groups of the proteins, such as cysteine and lysine, occurred during alkaline protein isolation process (Sosulski, 1979; Sahidi and Naczk, 2004). The results were similar to that of Adebowale et al., (2007) for Mucana bean protein isolate.

Table 4. Colour evaluation of protein isolate using a Minolta Chroma Meter CR-300

\begin{tabular}{lccc}
\hline $\begin{array}{l}\text { Protein } \\
\text { Isolate }\end{array}$ & L-value & a-value & b-value \\
\hline IP3 & $33.48 \pm 0.35$ & $1.56 \pm 0.33$ & $15.6 \pm 0.45$ \\
IP5 & $33.24 \pm 0.22$ & $1.08 \pm 0.11$ & $15.02 \pm 0.22$ \\
\hline
\end{tabular}

\section{Conclusion}

Nyamplung protein isolates that were obtained from the defatted nyamplung seeds cake by solubilisation-precipitation method at $\mathrm{pH} 3$ (IP3) and 5 (IP5), can be considered as a high quality protein since they have most of the essential amino acid. IP3 protein isolate differed significantly from IP5 with respect to both the capacity of water binding and foaming. Both isolates had excellent in emulsifying capacity. Since total polar amino acid was about 1.7 times higher than non-polar amino acid, it might result in high ratio of water-oil binding capacity and HLB. Nyamplung protein isolates also had a better gelation capacity. In conclusion, nyamplung protein isolates are better source of protein and may stabilize oil in water emulsion system.

\section{References}

Adebowale, K.O. and Lawal, O.S. 2003. Foaming, gelation and electrophoretic characteristics of mucuna bean (Mucuna pruriens) protein concentrates. Food Chem. 83: 237-246.

Adebowale, Y.A., Adeyemi, I.A., and Oshodi, A.A.K. 2007. Isolation, fractionation and characterization of protein from mucuna bean. J. Food Chem. 104: 287-299.

Aluko, R. and Yada, R.Y. 1995. Structure-function relationships of cowpea (Vigna unguiculata) globulin isolate: influence of $\mathrm{pH}$ and $\mathrm{NaCl}$ on physicochemical and functional properties. Food Chem. 53: 259-265.

AOAC. 1990. Official Methods of Analysis. $15^{\text {th }}$ edition. Association of Official Analytical Chemists. Washington D.C. USA.

Asralian. 2009. Pemurnian minyak nyamplung (Calophyllum inophyllum Linn) dengan degumming menggunakan air dan karakterisasinya sebagai biofuel. Tesis, Graduate Programme, Department of Food and Agricultural Product Technology, Gadjah Mada University, Yogyakarta, Indonesia.

Bustomi, S., Roswati, T., Sudrajat, R., Leksono, B., Kosasih, A.S., Anggraeni, I, Syamsuwida, D.M., Lisnawati, Y., Mile, Y., Djaenudin, D., Mahfudz., and Rachman, E. 2008. Nyamplung (Callophyllum inophyllum L.) sumber energi biofuel yang potensial. Litbang Kehutanan. Jakarta.

Chavan, U. D., McKenzie, D. B., and Shahidi, F. 2001. Functional Properties of protein isolates from beach pea (Lathyrus maritimus L.). J. Food Chem. 74: 117-187.

Cheng, J., Zhou, S., Wu, D., Chen, J., Liu, D., and Ye, X. 2009. Bayberry (Myrica rubra) kernel : A new protein source. J. Food Chem. 112: 469-473.

Crane, S., Aurore, G., Joseph, H., Mouloungui, Z., and Bourgeois, P. 2005. Composition of fatty acids triacylglycerols and unsaponifiable matter in Calophyllum calaba L. oil from Guadeloupe. Phytochemistry 66: 1825-1831.

Gandhi, A.P., and Srivastava, J. 2007. Studies on the production of protein isolates from defatted sesame seed (Sesamum indicum) flour and their nutritional profile. ASEAN Food J. 14: 175-180.

Hojilla-Evangelista, M.P., and Evangelista, R.L. 2009. Functional properties of protein from lesquerella fendleri seed and press 
cake from oil processing. Indian Crop. Prod. 29: 466-472.

Hung, S.C., and Zayas, J.F. 1991. Emulsifying capacity and emulsion stability of milk proteins and corn germ protein flour. J. Food Sci. 56: 1216-1218.

Jayasena, V., Chih, H.J., and Nasar-Abbas, S.M. 2010. Functional properties of sweet lupin isolated and tested at various $\mathrm{pH}$ levels. J. Agr. Biol. Sci. 6: 130-137.

Kaur, M. and Singh, N. 2007. Characterization of protein isolates from different Indian chickpea (Cicer arietinum L.) cultivars. Food Chem. 102: 366-374.

Laemmli, V.K. 1970. Cleavage of structural proteins during the assembly of the heads of bacteriophage T4. Nature. 227: 680685.

Lqari, H., Vioque, J., Pedroche, J., and Millan, F. 2002. Lupinus angusitifolius protein isolate: Chemical composition, functional properties and protein characterization. J. Food Chem. 76: 349-356.

Mahajan, A. and Dua, S. 1995. Functional properties of rapeseed protein isolates. J. Food Sci. Technol. 32: 162-165.

Makkar, H.P.S., Becker, K., Spore, F. and Wink, M. 1997. Studies of nutritive potential and toxic constituent of different provenances of jatropha curcas. L. J. Agr. Food Chem. 45: 3152-3157.

Manak, L.J., Lawhon, J.T., and Lusas, E.W. 1980. Functioning potential of soy, cottonseed and peanut protein isolates produced by industrial membrane systems. J. Food Sci. 45: 236-238.

Massoura, E., Vereijken, J.M., Kolster, P. and Derksen, J.T.P. 1998. Proteins from Crambe abyssinica oil seed. I. Isolation procedure. J. Am. Oil Chem. Soc. 75: 323327.

Naczk, M., Diosady, L.L., and Rubin, L.J. 1985. Functional properties of canola meals produced by a two phase solvent extraction system. J. Food Sci. 50: 16851692.

Pickardt, C., Neidhart, S., Griesbach, C., Dube, M., Knauf, U., Kammerer, D.R., and Carle, R. 2009. Optimization of mild-acidic protein extraction from defatted sunflower (Helianthus annuus L.) meal. Food Hydrocoll. 23: 1966-1973.
Rodriguez-Ambriz, S.L., Martinez-Ayala, A.L., Millan, F., and Davila-Ortiz, G. 2005. Composition and functional properties of Lupinus campestris protein isolates. Plant Food Hum. Nutr. 60: 99-107.

Sahidi, F. and Naczk, M. 2004. Phenolics in Food and Neutraceuticals. Boca Raton, FL: CRC Press.

Sathe, S.K., Deshpande, S.S., and Salunkhe, D.K. 1982. Functional properties of lupin seed (Lupinus mutabilis) proteins and protein concentrates. J. Food Sci. 7: 191-197.

Sosulski, F.W. 1979. Organoleptic and nutritional effects of phenolic compounds on oilseed protein products: a review. J. Am. Oil Chem. Soc. 56: 711-715.

Sudradjat. 2009. Forest products research and development centre has accomplished research on manufacturing nyamplung biodiesel (Calophyllum inophyllum L.) (Year 2005- 2008) http://www.dephut.go.id/files/Nyamplun g_ En.pdf, Access, 29-07-2009.

Tsaliki, E., Pegiadou, S. and Doxastakis, G. 2003. Evaluation of the emulsifying properties of cottonseed protein isolates. Food Hydrocolloid. 18: 631-637.

Venkanna, B.K. and Reddy, C.V. 2009. Biodiesel production and optimization from Calophyllum inophyllum linn oil (honne oil) - A three stage method. Bioresource Technol. 100: 5122-5125.

Yoshie-Stark, Y., Wada, Y., and Wasche, A. 2008. Chemical composition, functional properties, and bioactives of rapeseeds protein isolates. J. Food Chem. 107: 32-39.

Zhang, T., Jiang, B., and Wang, Z. 2007. Gelation properties of chickpea protein isolates. Food Hydrocolloid. 21: 280-286.

Zayas, J.F. 1997. Functionality of Protein in Food. Springer-Verlag, Berlin Heidelberg. 